\title{
In memoriam of Prof. Dr. h.c. mult. Otto Prokop, MD
}

\author{
Gunther Geserick $•$ Michael Tsokos
}

(C) Springer-Verlag 2009

On January 20, 2009, Prof. Dr. h.c. mult. Otto Prokop, MD, died at the age of 87. Otto Prokop was born in St. Pölten, Lower Austria, on September 29, 1921. He took his Alevels in Salzburg, Austria. He had to interrupt his medical studies because of his military service; he finished them in Vienna, Austria and Bonn, Germany. In 1948, he received a doctorate under Herbert Elbel at the University of Bonn, Germany, and in 1953, he obtained his habilitation (postdoctoral university degree with lecture qualification) in Legal Medicine.

In 1957, he was appointed to a chair of Forensic Medicine at the Humboldt University of Berlin, Germany. There, he held a chair and was the Director of the Institute of Legal Medicine of the Charité, until he was conferred the emeritus status in 1987. In addition, he was the interim director of the Institutes of Legal Medicine in Leipzig, Germany (1958-1961) and Halle, Germany (1958-1959).

As a university lecturer, Prof. Prokop inspired thousands of students (medical students, criminologists and law students) over decades with his refined oratorical style, on the highest scientific level, and with his charming humour. His scientific estate documents his long-time, exceptional productivity, including more than 650 original papers, still successful standard works on the subject (e.g. "Forensische Medizin", "Atlas der gerichtlichen Medizin", "Die menschlichen Blutgruppen", "Genetik" etc.) as well as mono-

G. Geserick $\cdot$ M. Tsokos $(\bowtie)$

Institute of Legal Medicine of the Charité,

University Medicine of Berlin,

Berlin, Germany

e-mail: rechtsmedizin@charite.de

M. Tsokos

State Institute of Legal and Social Medicine of Berlin, Berlin, Germany graphs on occultism, charlatanry and pseudosciences, which he confronted vigorously. His books were translated and issued in England, Italy, Japan, Canada, Poland, Spain, the former USSR and the USA.

Otto Prokop exemplified the dedicated connection of teaching and research. Numerous discoveries in the field of blood group research and fundamental findings in forensic pathology, traumatology and stain evidence are both the result of his tireless and focused work and of his unorthodox spirit.

Twenty-five physicians from Germany and abroad habilitated under Otto Prokop. Many of his students became university lecturers or directors of other institutes of Legal/Forensic Medicine. Together with his German and foreign students, doctoral candidates and auditors, they are witnesses of Prokop's school, which became a symbol for strict science (even excluding courtesy expert reports issued in the interest of political rulers), soundness in knowledge and skills as well as human warmth and tolerance.

On the occasion of his 80th birthday, the jubilarian was recognised by Bernd Brinkmann, the then-President of the German Society of Legal Medicine, "as one of the most outstanding forensic pathologists of the last century, who was one of the last persons to understand the subject in its full width, to apply it practically and to actively help shape it in research".

Thus, it is not surprising that the list of awards and honorary memberships in Germany and abroad is long; a special focus should be placed on the honorary doctorates in Leipzig, Germany, Szeged, Hungary, and Tokyo, Japan, as well as the membership in the German Academy of Sciences Leopoldina.

The subject-specific knowledge and the personal attitude of the professor emeritus were also in demand after the German Reunification, for example, in senate committees and investigating committees of the State of Berlin, 
Germany. Even after he retired, Otto Prokop was working in his old institute at the Charite in the Hannoversche Straße for many years. Generations of students, pupils and former colleagues in Germany and abroad are indebted to him for the professional and human education and for always being a reliable supporter and adviser.
The great sympathy that was triggered by the death of Otto Prokop is reflected in numerous obituaries in Berlin press and television. Otto Prokop did not only change the image of German Legal Medicine but also the image of the Charité. We are mourning for an outstanding scientist, university lecturer, physician and forensic pathologist. 